\title{
Cost of a drip irrigation system for vegetable farming in Puerto Rico'
}

\author{
Tillak Persaud, Megh R. Goyal, and Philippe Bellerive ${ }^{2}$
}

\begin{abstract}
This report presents the cost of a drip irrigation system for vegetable farming in Puerto Rico. The total initial cost of establishing an automatic drip irrigation system on a 4.36 hectare farm was $\$ 28,639.03,10.79 \%$ of which was for pump house facilities; $3.1 \%$ for filter with accessories; $2.95 \%$

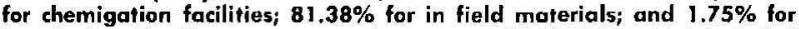
installation. The first year cost per hectare was $\$ 1,976.72$, which included depreciation, interest, maintenance and installation. A computer program was developed to calculate these costs.
\end{abstract}

\section{INTRODUCTION}

The commercial use of drip irrigation in Puerto Rico has meant significant real returns to farmers. It can be especially suitable for the farmers located on Puerto Rico's south coast, where long droughts often occur. Drip irrigation results in high water use efficiency. Cost was not a crucial factor during past prosperous years, but now, with high energy costs for pumping, declining levels of water resources have rendered the decision on which irrigation system to use as important as the basic decision to irrigate (2).

With other methods of irrigation, a farmer used to irrigate his crop as well as the weeds. However, the use of a drip irrigation system increases the crop-water efficiency $(1,5,6)$. In Hawaii, where sugarcane labor cost can be as high as $\$ 10$ per hour, drip irrigation can provide a substantial saving on labor cost $(3,4)$.

In some countries, the training in drip irrigation techniques has been difficult because of psychological factors. Some workers cannot believe that they are irrigating where there is little mud and the leaves of the crops are not wet (5). Lack of appropriate information about costs and benefits creates resistance to the adoption of this new technology.

'Manuscript submitted to Editorial Board 17 February 1987.

This study was conducted under CBAG-28, "Irrigation Estimations in Puerto Rico." The authors thank Caribbean Irrigation Sales, Inc., Santa Isabel, Puerto Rico for their cooperation in this study.

${ }^{2}$ Associate Economist, Associate Agricultural Engineer and Graduate Student, Agricultural Experiment Station, University of Puerto Rico-Mayagüez Campus, Río Piedras, Puerto Rico. 


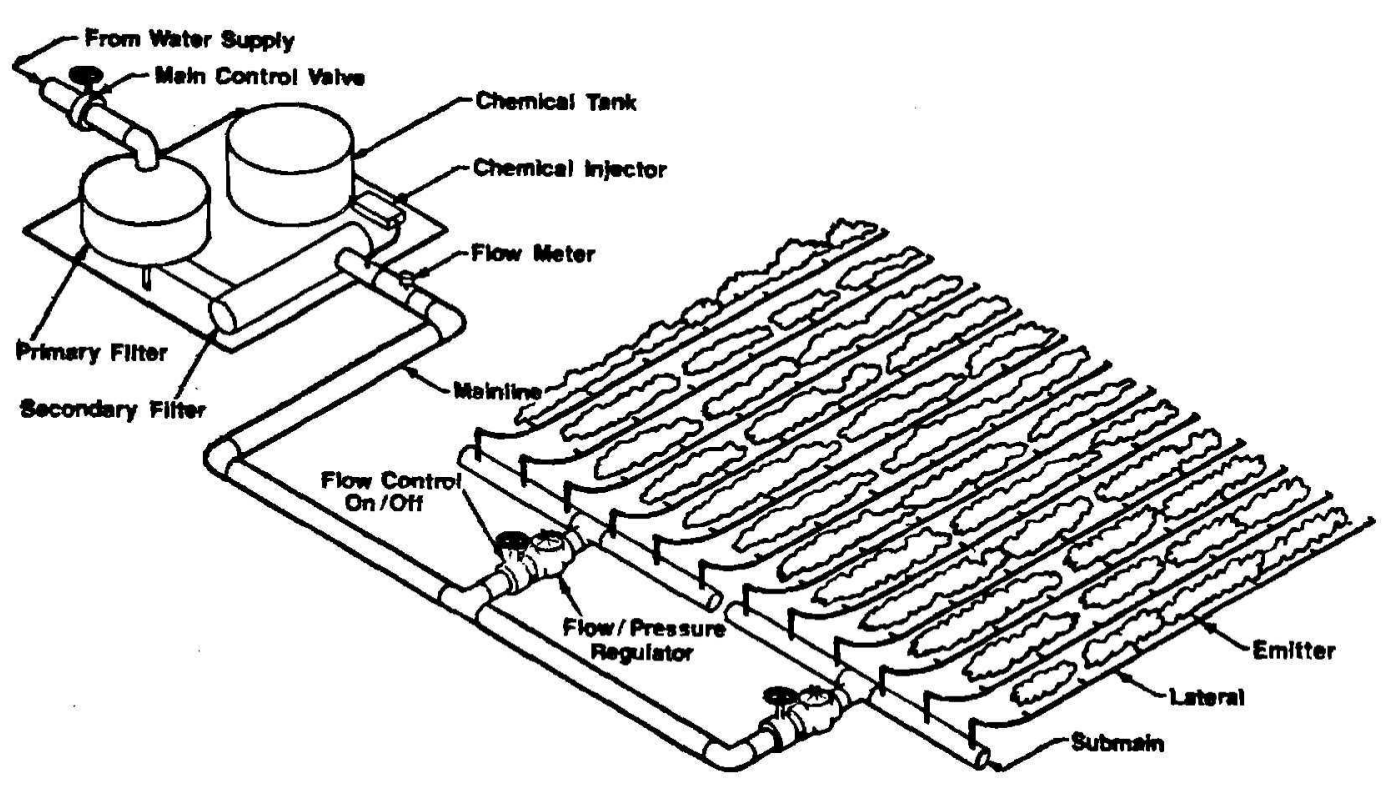


The purpose of this study is to provide information to vegetable farmers in Puerto Rico so that they can evaluate the yearly costs of adopting a drip irrigation system as an alternative method of producing vegetable crops.

\section{MATERIALS AND METHUDS}

A drip irrigation system was designed for a hypothetical vegetable farm of 4.36 hectares (10.89 acres) shown in figure 1 . The cost of materials ${ }^{3}$ for this system is indicated in table 1 . The prices of system components are for the year 1986 and were quoted by Caribbean Irrigation Sales Inc. Santa Isabel, Puerto Rico. ${ }^{4}$

TABLE 1.-Bill of Materials for Installation of a Drip Irrigation on a 4.86-hectare (10.89 acre) Farm

\begin{tabular}{|c|c|c|c|c|c|}
\hline $\begin{array}{l}\text { Serial } \\
\text { No. }\end{array}$ & Item & Unit & Quantity & $\begin{array}{l}\text { Cost (\$) } \\
\text { per unii }\end{array}$ & Cost (\$) \\
\hline \multirow[t]{13}{*}{ I. } & Pump house facilities: & & & & \\
\hline & $\begin{array}{l}\text { 1. Centrifugal pump with electrical } \\
\text { motor } 5 \mathrm{hp} \text {., } 230 \mathrm{~V} \text {. single phase; } \\
\text { suction/discharge fittings; }\end{array}$ & & & & \\
\hline & magnetic starter & ea. & 1 & $1,850.00$ & $1,850.00$ \\
\hline & 2. Controller with pump starter & ea. & 1 & 508.00 & 508.00 \\
\hline & $\begin{array}{l}\text { 3. Solenoid valve }(7.5 \mathrm{~cm} \text {. plastic } \\
\text { body) }\end{array}$ & & & & \\
\hline & 4. Unions $(7.5 \mathrm{~cm} . \mathrm{Gl})$ & $\begin{array}{l}\text { ea. } \\
\text { ea. }\end{array}$ & $\begin{array}{l}3 \\
3\end{array}$ & $\begin{array}{r}202.54 \\
27.82\end{array}$ & $\begin{array}{r}607.62 \\
83.46\end{array}$ \\
\hline & 5. Male adapter $(7.5 \mathrm{~cm})$ & ea. & 3 & 21.02 & 00.40 \\
\hline & PVC Sch. 40 & ea. & 2 & 4.86 & 9.72 \\
\hline & 6. Teflon tape & ea. & 3 & 1.00 & 3.00 \\
\hline & 7. Wire connector & box & 1 & 7.56 & 7.56 \\
\hline & 8. Eilectric cable (\#18) & $\mathrm{m}$ & 15 & 0.17 & 2.55 \\
\hline & 9. Sealer & ea. & 1 & 19.00 & 19.00 \\
\hline & & & & abtotal I & $\overline{3,090.91}$ \\
\hline \multirow[t]{10}{*}{ II. } & Filter with fittings: & & & & \\
\hline & 10. Screen filter 200 mesh & ea. & 1 & 820.00 & 820.00 \\
\hline & 11. Victaulic adapter $(7.5 \mathrm{~cm}$.) & & & & \\
\hline & PVCSch 40 & ea. & 3 & 7.92 & 23.76 \\
\hline & 12. Coupler $(7.5 \mathrm{~cm})$. & & & & \\
\hline & PVC Sch 40 & ea. & 3 & 7.40 & 22.20 \\
\hline & 13. Slip coupler $(7.5 \mathrm{~cm}$.) & & & & \\
\hline & PVCSch 40 & ea. & 2 & 4.17 & 8.34 \\
\hline & 14. Elbow $(7.5 \mathrm{~cm}, \times 90)$ & & & & \\
\hline & PVC Sch 40 & ea. & 3 & $\begin{array}{r}8.40 \\
\text { ubtotal II }\end{array}$ & $\begin{array}{r}25.20 \\
-899.50\end{array}$ \\
\hline
\end{tabular}

'Yarnton, D., 1986. Personal communication, Caribbean Irrigation Sales, Inc., Santa Isabel, Puerto Rico.

Trade names in this publication are used only to provide specific information. Mention of a trade name does not constitute a warranty of equipment of materials by the Agricultural Experiment Station of the University of Puerto Rico, nor is this mention a statement of preference over other equipment or materials. 
TABLE 1.-(Continued)

\begin{tabular}{|c|c|c|c|c|c|}
\hline $\begin{array}{l}\text { Serial } \\
\text { No. }\end{array}$ & Item & Unit & Quantity & $\begin{array}{l}\text { Cost (\$) } \\
\text { per unit }\end{array}$ & Cust (\$) \\
\hline \multirow[t]{23}{*}{ III. } & Chemigation accessories: & & & & \\
\hline & 15. Fertilizer tank (stainless steel) & ea. & 1 & 662.24 & 662.24 \\
\hline & 16. Slip tee $(7.5 \mathrm{~cm}$.) PVC Sch 40 & ea. & 2 & 11.73 & 28.46 \\
\hline & 17. Bushing $(5 \mathrm{~cm} . \times 2.5 \mathrm{~cm}$. $)$ & & & & \\
\hline & PVC Sch 40 & ea. & 2 & 1.39 & 2.78 \\
\hline & 18. Bushing $(7.5 \mathrm{~cm} . \times 5 \mathrm{~cm})$. & & & & \\
\hline & PVC Sch 40 & ea. & 2 & 3.09 & 6.18 \\
\hline & 19. Elloow $\left(2.5 \mathrm{~cm} . \times 90^{\circ}\right)$ & & & & \\
\hline & PVC Sch 40 & ea. & 6 & 0.96 & 5.76 \\
\hline & 20. Pipe $(2.5 \mathrm{~cm}$.$) PVC Sch 40$ & $\mathrm{~m}$ & 9 & 1.10 & 9.90 \\
\hline & 21. Gate valve $(2.5 \mathrm{~cm}$.) bronze & ea. & 3 & 4.92 & 14.76 \\
\hline & 22. Male adapter $(2.5 \mathrm{~cm})$. & & & & \\
\hline & PVCSeh 40 & ea. & 7 & 0.54 & 3.78 \\
\hline & 23. Reducer $(2.5 \mathrm{~cm}, \times 1.875 \mathrm{~cm}$. & & & & \\
\hline & PVC Sch 40 & ea. & 2 & 1.08 & 2.16 \\
\hline & 24. Close nipple $(1.875 \mathrm{~cm}$.) GI & ea. & 2 & 0.40 & 0.80 \\
\hline & 25. Close nipple $(1.25 \mathrm{~cm}$. $) \mathrm{Gl}$ & ea. & 1 & 0.32 & 0.32 \\
\hline & 26. Reducer $(2.5 \mathrm{~cm}, \times 1.25 \mathrm{~cm}$.) GI & ea. & 1 & 2.12 & 2.12 \\
\hline & 27. Flowmeter $(2.5 \mathrm{~cm}$.) & & & & \\
\hline & Acrylic plastic & ea. & 1 & 33.98 & 33.98 \\
\hline & 28. PVC cement' & qt & 12 & 5.90 & 70.80 \\
\hline & 29. Teflon tape ${ }^{1}$ & ea. & 6 & 1.00 & 6.00 \\
\hline & & & & btotal III & 845.04 \\
\hline
\end{tabular}

IV. In field materials:

30. Drip tubing with emitter

(2 1 ph.) spaced $60 \mathrm{~cm}$. and

based upon $1.8 \mathrm{~m}$. bed spacing

31. Saddle $(16 \mathrm{~mm}$.) poly

32. Strap poly

33. Insert tee $(16 \mathrm{~mm}$.) poly

34. Insert elbow $(16 \mathrm{~mm}$.) poly

35. Insert connector ( $16 \mathrm{~mm}$.) poly

36. Plug ( $16 \mathrm{~mm}$.) poly

37. Poly tubing $(16 \mathrm{~mm}$.)

38. Pressure regulator $(5 \mathrm{~cm}$.) brass

39. Gate valve $(5 \mathrm{~cm}$.) bronze

40. Gate valve $(7.5 \mathrm{~cm}$.) bronze

41. Male adapter $(5 \mathrm{~cm}$.) PVC $\mathrm{Sch} 40$

42. Male adapter $(7.5 \mathrm{~cm}$.) PVC Sch 40

43. Elbow $(5 \mathrm{~cm} . x 90 @$ ) PVC Sch 40

$\begin{array}{rrrr}\text { m } & 24,000 & 0.72 & 17,280.00 \\ \text { ea. } & 190 & 0.63 & 119.70 \\ \text { ea. } & 190 & 0.84 & 159.60 \\ \text { ea. } & 140 & 0.84 & 117.60 \\ \text { ea. } & 60 & 0.26 & 15.60 \\ \text { ea. } & 90 & 0.48 & 43.20 \\ \text { ea. } & 330 & 0.22 & 72.60 \\ \text { m } & 300 & 0.40 & 120.00 \\ \text { ea. } & 10 & 0.48 & 43.20 \\ \text { ea. } & 10 & 13.46 & 134.60 \\ \text { ea. } & 3 & 38.40 & 115.20 \\ \text { ea. } & 40 & 2.19 & 87.60 \\ & & & \\ \text { ea. } & 6 & 4.86 & 29.16 \\ \text { ea. } & 40 & 2.73 & 109.20 \\ \text { ea. } & 10 & 8.40 & 84.00 \\ \text { ea. } & 1 & 1.05 & 1.05 \\ \text { ea. } & 9 & 0.97 & 8.73 \\ \text { ea. } & 10 & 11.73 & 117.30 \\ & & & \\ \text { ea. } & 3 & 4.17 & 12.51\end{array}$

44. Elbow $(7.5 \mathrm{~cm} . \times 90$ (20)

45. Slip cap $(3.75 \mathrm{~cm}$.) PVC Sch 40

46. Slip eap ( $5 \mathrm{~cm}$.) PVC Sch 40

47. Slip tee $(7.5 \mathrm{~cm}$.) PVC Sch 40

48. Slip coupler $(7.5 \mathrm{~cm}$ )

PVC Sch 40$$
\text { . }
$$ 
TABLE 1.-(Continued)

\begin{tabular}{|c|c|c|c|c|c|}
\hline $\begin{array}{c}\text { Serial } \\
\text { No. }\end{array}$ & Item & Unit & Quantity & $\begin{array}{l}\text { Cost (\$) } \\
\text { per unit }\end{array}$ & Cost (\$) \\
\hline & 49. Bushing $(5 \mathrm{~cm} . \times 3.75 \mathrm{~cm})$. & & & & \\
\hline & PVC Sch 40 & ea. & 1 & 1.65 & 1.65 \\
\hline & 50. Bushing $(7.5 \mathrm{~cm} . \times 5 \mathrm{~cm}$.) & ea. & 12 & 3.09 & 37.08 \\
\hline & 51. Pipe $(3.75 \mathrm{~cm}$.) PVC Sch 40 & $\mathrm{m}$ & 90 & 1.80 & 162.00 \\
\hline & 52. Pipe (5 cm.) PVC Sch 40 & $\mathrm{~m}$ & 300 & 2.80 & 840.00 \\
\hline & 53. Pipe $(7.5 \mathrm{~cm}$.) PVC Sch 40 & $\mathrm{m}$ & 300 & 5.27 & $1,581.00$ \\
\hline & & & & Subtotal IV & $23,303.58$ \\
\hline \multirow[t]{4}{*}{ v. } & Installation (tabor): & - & - & 一 & $\begin{array}{r}500.00 \\
2809\end{array}$ \\
\hline & Cost/ha & & & & $6,568.58$ \\
\hline & Cost/ac. & & & & $2,629.85$ \\
\hline & Cost/cda. & & & & $2,554.11$ \\
\hline
\end{tabular}

IUsed for system installation.

Annual cost of a drip irrigation system consists of depreciation, interest, operation, maintenance and installation. Useful life of 15 years was assumed for all system components except for a useful life of 5 years for lateral drip lines. Salvage value was assumed to be zero. The straightline method was used to compute depreciation. This study used a $9.75 \%$ annual interest rate to calculate interest payments. This is the current rate charged by the Agricultural Credit Corporation (ACC) of Puerto Rico for farm loans. Annual operational and maintenance costs were calculated on the basis of $5 \%$ of total cost of the drip system, except for drip tubing, for which $20 \%$ of initial cost was used, based upon experiences in the field. Installation cost calculation was based on estimates made by the University of Hawaii (7). Hourly rates $(7,9)$ were assumed to be $\$ 3.35$ for field labor, $\$ 8.90$ for tractor with driver. Total installation cost was $\$ 500$, consisting of $\$ 268$ for farm labor, $\$ 178$ for tractor use, and $\$ 54$ for miscellaneous tasks.

Although loans are paid off by the farmer on a monthly basis, in this case the interest payment was calculated on an annual basis. Different repayment schedules could be worked out between the lending institution and the farmer. However, this study used the amortized equal payment method. Table 2 lists a computer program which calculates the depreciation, interest payments, and the loan balance. This program is written in Basic, is interactive, and can be run on many types of microcomputers.

It should be noted that these costs can be reduced according to the financial resources of the farmer. Tables 3 and 4 show yearly cost components. 
TABLE 2-Computer program to caleulate depreciation and loan amontization

100 Print "Depreciation and loan amortization"

110 Print

120 Input "Straight-line depreciation $(0=n 0,1=$ yes $)$ "; $s \mathrm{Im}$

130 If $\mathrm{slm}=0$ goto 290

140 Print

150 Input "Original cost $=\$ " ; c$

160 Print

170 Input "Salvage value $=\$ "$,s

180 Print

190 Input "Year of useful service $=" ; y$

$200 \mathrm{D}=(\mathrm{c}-\mathrm{s}) / \mathrm{y}$

$210 \mathrm{D}=\operatorname{Int}\left(\mathrm{d}^{*} 100+.05\right) / 100$

220 Print "yr";spe(5);"cost";spe(4); "salvage";spe(4);"depr";spe(5);"balance"

230 Fo $n=0$ to $y$

240 If $\mathbf{n}=0$ goto 28

$250 \mathrm{~B}=\mathrm{c}-\mathrm{d}^{*} \mathrm{n}$

$260 \mathrm{~B}=\operatorname{Int}\left(\mathrm{b}^{*} 100+.05\right) / 100$

270 Print $n ; s p c) 3$;); ;pe(4);s;spc(4);d;spc(4);b

280 Next $n$

290 Print

300 Input "Loan amortization $(0=$ no, $1=$ yes)"; 1 a

310 If la $=0$ goto 530

320 Print

330 Input "Amount of loan $=\$ " ; 1$

340 Print

350 Input "Yearly interest rate $=$ "; $r$

$360 \mathrm{I}=\mathrm{r} / 100$

370 Print

380 Input "Number of years $=$ ";

390 Print

400 Input "Number of payments per year $=$ ";n

$410 \mathrm{Tn}=\mathrm{t}^{*} \mathrm{n}$

420 Print

430 Print "yr";spe(4);"paymt";spe(5); "intrst";spc(5);"princpl";spe(5);"balance"

$440 \mathrm{Rp}=\left(\mathrm{L}^{*} \mathrm{~L} / \mathrm{n}\right) /(\mathrm{l}-/(\mathrm{l}+\mathrm{L} / \mathrm{n})-\mathrm{tn}$

$450 \mathrm{Rp}=\operatorname{Int}(\mathrm{Rp} * 100+.05) / 100$

460 For $x=0$ To tn

470 If $\mathrm{x}=0$ Then 590

$480 \mathrm{Ip}=\operatorname{Int}\left(\mathrm{L}^{*} \mathrm{I} / \mathrm{n}^{*} 100+.05\right) / 100$

$\left.490 \mathrm{Ap}=\operatorname{Int}\left((\operatorname{Rp}-\mathrm{Ip})^{*} 100+.05\right)\right) / 100$

$500 \mathrm{~L}=\operatorname{Int}((\mathrm{L}-\mathrm{ap}) * 100+.05)) / 100$

510 Print $x ; s p c(2) ; r p ; s p c(2) ; i p ; s p c(6) ; a p ; s p c(5) ; 1$

520 Next $x$

580 Print

540 Print "Do you want to continue?"

550 Input "New data $(0=$ no, $1=$ yes $)$ ";zz

660 If $\mathrm{zz}=1$ then 110

570 End 


\section{RESULTS AND DISCUSSION}

The total cost of acquiring and establishing a drip irrigation system for a vegetable farm on the south coast of Puerto Rico is $\$ 28,639.03$. Table 1 is a breakdown of the components and cost of the system.

The drip system is categorized into five subsystems. Subsystem I comprises the pump house facilities, which cost $\$ 3,090.91$ or $10.8 \%$ of the total initial cost of the drip system (table 1). Subsystem II includes the filter with fittings which cost $\$ 899.50$ (or $3.1 \%$ of the total initial cost). Subsystem III represents the chemigation accessories which cost $\$ 845.04$ (or $3.0 \%$ of the initial cost). Subsystem IV consists of the in field materials and costs $\$ 23,303.58$ (or $81.3 \%$ of the total initial cost). The cost of installing the drip system is $\$ 500$. (The reason Subsystem IV is the most costly is that the drip tubing costs $\$ 17,280$.)

Table 3 presents the first year cost of the drip irrigation system consisting of depreciation, interest payment, and operation and maintenance. Depreciation calculated by the computer program was $\$ 1,875.94$ for the first year.

Interest payment was calculated on a principal of $\$ 28,639.03$, the cost of the drip system, at an annual rate of $9.8 \%$. Interest payment for the first year calculated by the computer program was $\$ 2,743.55$. The first year operation and maintenance cost is $\$ 3,998.92$. Thus, the total first year cost was $\$ 9,118.41$. This total reflects $\$ 500$ for installing the system because this amount will be incurred in the first year of operation (table 3).

Table 4 shows the annualized cost of the system for 15 years. Again, these annualized costs reflect depreciation, interest payments, operation and maintenance for the entire drip system. It should be noted that the total annualized costs for the 1st, 6th and 11th years are higher than for the intervening years. For example, the total annualized cost for the first year is $\$ 9,118.41$ and for the 5 th year it is $\$ 8,211.22$. But for the 6 th year, it is $\$ 9,768.23$. The reason why total annualized cost is higher for the 6 th year than the 5th year, and for the 11th year than the 10th year is the cost of replacing the drip tubing after 5 years. The cost of replacing the drip tubing is $\$ 17,280$, which increases the total annual cost. Furthermore, it should be noted that the total annual cost for the 6th year is higher than for the 1st year and for the 11th year higher than for the 6th year. The cost of replacing the drip tubing is the most important cost in a drip irrigation system. The economic feasibility of the system will depend very much on this cost, among other production factors. Total annual cost can be reduced if the useful life of the drip tubing can be extended beyond 5 years. 
TABLE 3.-First year cost of drip irrigation system

\begin{tabular}{|c|c|c|c|c|c|c|c|c|}
\hline \multirow{2}{*}{\multicolumn{2}{|c|}{ Subsystems $^{2}$}} & \multicolumn{2}{|c|}{ Initial costs (\$) } & \multicolumn{5}{|c|}{ Cost (\$ year)' } \\
\hline & & $\$$ & $\begin{array}{l}\% \text { of total } \\
\text { initial cost }\end{array}$ & $\begin{array}{c}\text { Service } \\
\text { life }\end{array}$ & $\begin{array}{c}\begin{array}{c}\text { Depreciation } \\
(\$)\end{array} \\
\end{array}$ & $\begin{array}{c}\text { Interest } \\
\text { (\$) }\end{array}$ & $\begin{array}{l}\text { Operation and } \\
\text { maintenance } \\
(\$)\end{array}$ & $\begin{array}{c}\text { Total } \\
(\$)\end{array}$ \\
\hline I. & Pump house facilities & $3,090.91$ & 10.79 & 15 years & 206.06 & 301.36 & 154.55 & 661.97 \\
\hline II. & Filter with fittings & 899.50 & 3.14 & 15 years & 59.97 & 87.70 & 44.98 & 192.65 \\
\hline III. & Chemigation accesories & 845.04 & 2.95 & 15 years & 56.34 & 82,39 & 42.25 & 180.98 \\
\hline IV. & In field materials ${ }^{3}$ & $23,303.58$ & 81.37 & 15 years' & $1,553.57$ & $2,272.10$ & $3,757.14$ & $7,582.81$ \\
\hline \multirow[t]{5}{*}{ V. } & Installation (labor) & 500.00 & 1.75 & & & & & \\
\hline & Initial Cost & $28,639.03$ & 100.00 & & $1,875.94$ & $2,743.55$ & $3,998.92$ & $9,118.41$ \\
\hline & Cost/ha & $6,568.58$ & - & - & 430.26 & 629.25 & 917.18 & $2,091.38$ \\
\hline & Cost/acre & $2,626,85$ & - & - & 172.26 & 251.93 & 367.21 & 837.32 \\
\hline & Cost/cda. & $2,554.11$ & - & - & 167.30 & 244.68 & 356.63 & 813.20 \\
\hline
\end{tabular}

'Based upon a 15-year depreciation, $9.75 \%$ annual interest, and $5 \%$ of initial cost for operation and maintenance except drip tubing, which is $20 \%$ of initial cost.

"Bill of materials is indicated in Table 1.

${ }^{3}$ The service life of drip tubing is 5 years. 


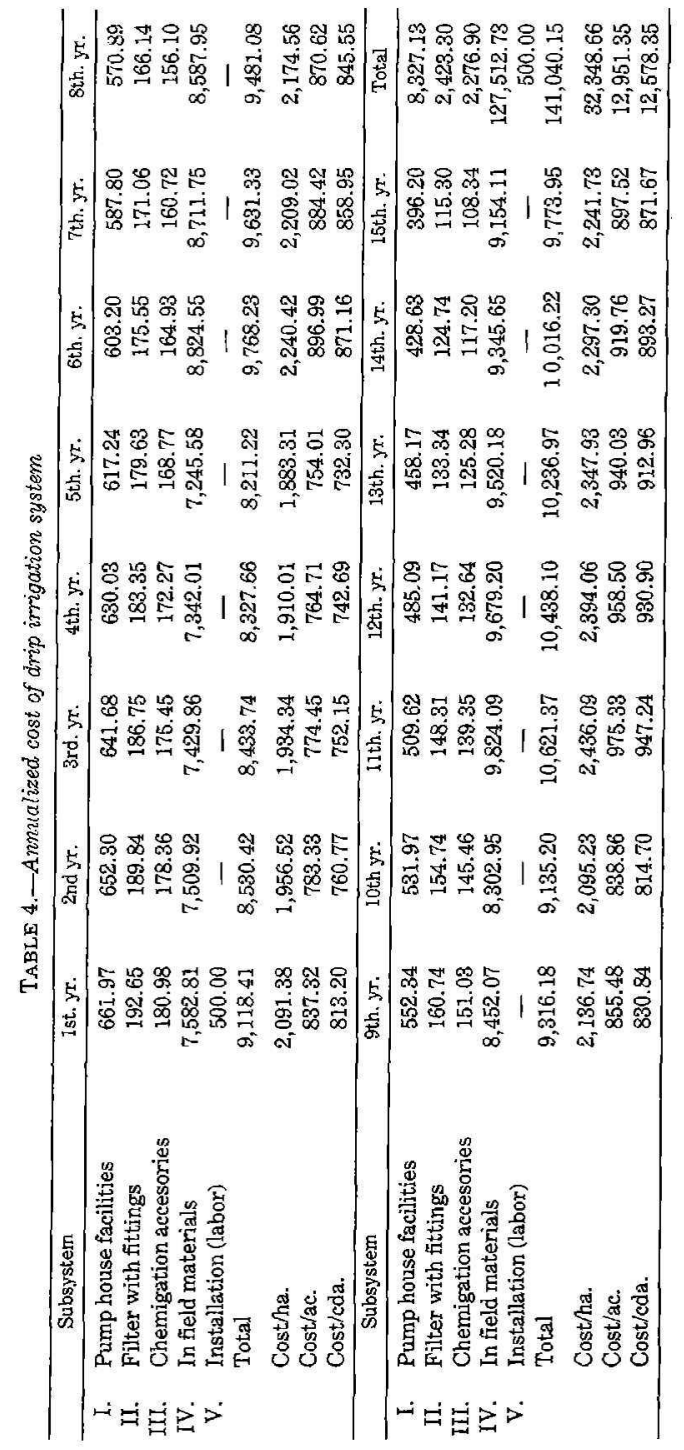




\section{RESUMEN}

Costo de un sistema de riego por goteo para una finca de hortalizas en Puerto Rico

Este informe presenta el costo de un sistema de riego por goteo para una finca de hortalizas en Puerto Rico. El costo total inicial de establecer un sistema de riego por goteo automático para una finca de 4.36 hectáreas fue de $\$ 28,639.03$, de los cuales $\mathbf{1 0 . 8 \%}$ son por la instalación de la casa de bombeo; $3.1 \%$ para el sistema de filtración; $3.0 \%$ para la tubería; $81.4 \%$ para los materiales de campo y $1.8 \%$ para la instalación. El costo por hectárea del primer año fue de $\$ 1,976.72$ que incluía la depreciación, el interés, el mantenimiento y la instalación. Se desarrolló un programa para microcomputadores para calcular estos costos.

\section{LITERATURE CITED}

1. Agricultural Engineer's Yearbook, 1982. Design, installation, and performance of trickle irrigation system. ASAE Yearb., pp. 519-22.

2. Freivalds, J., 1982. More than just water: Irrigation economics. Agribusiness Worldwide, November-December.

3. Gitlin, H. M., 1976. Drip irrigation installation: Commonly used parts. Engineer's Notebook, Cooperative Ext. Serv., Univ. Hawaii, No. 27.

4. Gitlin, H. M., 1976. A typical drip irrigation system installation. Engineer's Notebook, Coop. Ext. Serv., Uniy. Hawaii, No. 28.

5. Goyal, M. R. and L. E. Rivera, 1984. Principles of drip irrigation. Agric. Ext. Serv., Univ. P. R., Series No. 3.

6. Howard, T. J. and C. L. Anderson, 1980. Planning for an irrigation system. Association for Vocational Instructional Materials, Engineering Center, Athens, Georgia.

7. Huang, W. Y., D. K. J. Kahara and H. Yamauchi, 1979. Cost of drip irrigation for papaya. Haes PJ462, Hawaii Agxic. Exp. Stn., Univ. Hawaik, Paper 63.

8. Sosa, H. A., 1962. Farm Records. Agric. Ext. Serv., Univ. P. R., Río Piedras. 